\title{
HOGYAN MENEDZSELJÜK A KÖNYVTÁROSOK KOMPETENCIÁIBAN TÖRTÉNÖ VÁLTOZÁSOKAT, ÉS HOGYAN FEJLESSZÜK A FELSŐOKTATÁSI TANULMÁNYI PROGRAMOKAT?
}

\section{BAIBA HOLMA}

\section{Tartalmi összefoglaló}

A tanulmány célja, hogy jellemezze azokat a fó információforrásokat, amelyeket a könyvtár- és tájékoztatástudományi tanulmányi programok fejlesztésénél fel lehet használni, illetve, hogy megnevezze a tanulási folyamat fó kihívásait. A tanulmány azokra a tapasztalatokra épül, amelyeket a szerzö a Lettországi Egyetem Társadalomtudományi Karán az Információmenedzsment tárgy bachelor szintü tanulmányi programjának vezetöjeként szerzett.

https://doi.org/10.46280/KOMPKONF.2020.Holma

\section{Bevezetés}

Az információs és kommunikációs technológiák fejlődésének eredményeképpen a könyvtár- és információtudomány napjainkban az egyik legdinamikusabb terület. A társadalom bővelkedik az információhoz való hozzáférési lehetőségekben, és azt kívánja, hogy változtassuk meg az információforrások kezelésének régi módszereit, fejlesszük az információs szolgáltatásokat és adjunk új szerepet a könyvtáraknak és a könyvtárosoknak.

A könyvtárosok és más információs szakemberek számára releváns tudást és készségeket szeretnénk biztosítani, ezért a felsőoktatási és szakképzésben a tanulmányi programokat rendszeresen felül kell vizsgálni. A fö kérdés az, hogyan menedzseljük a könyvtárosok kompetenciáiban zajló változásokat, és hogyan fejlesszük a felsőoktatási tanulmányi programokat? Ez a tanulmány arra vállalkozik, hogy ismertesse a szükséges kompetenciák fó forrásait, és elemezze a tanulmányi programok fejlesztésével kapcsolatos kihívásokat.

\section{A kompetenciák forrásai}

Minden szakterületnek megvan a saját kompetenciakészlete, mely segít abban, hogy a társadalom és az egyének szükségleteit minél jobban ki tudjuk szolgálni, és ennek érdekében bizonyos feladatoknak és céloknak eleget tegyünk. A kompetencia fogalmát többféleképpen 
értelmezik általában, e tanulmányban a következőképpen használjuk: „a kompetencia az a képesség, amelynek révén a tudást, készségeket és személyes, szociális és/vagy módszerekkel kapcsolatos képességeket valamely munka elvégzéséhez és a szakmai fejlödéshez fel tudjuk

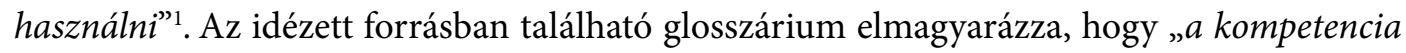
nem korlátozódik a kognitív elemekre (ebbe a körbe tartozik az elmélet, a fogalmak vagy a hallgatólagos tudás felhasználása); felöleli a funkcionális szempontokat (köztük a technikai készségeket), valamint az interperszonális attribútumokat (pl. a szociális vagy szervezési készségeket) és az etikai értékeket is.” Fontos hangsúlyozni azt, hogy „a kompetenciák a készségek, ismeretek, képességek, magatartások és más jellemzők megfigyelhető és mérhető mintázatai, amelyekkel egy egyénnek rendelkeznie kell ahhoz, hogy a munkája során betöltött szerepben és a foglalkozása keretében betöltött funkcióban sikeres lehessen."3

A szakmai identitást maguk a kompetenciák alkotják, és a kompetenciákat a társadalmi kontextus formálja és alakítja. Huvila és szerzőtársai ${ }^{4}$ rámutatnak, hogy ha változások jelentkeznek ebben az összefüggésrendszerben, változásokra van szükség a szakmai identitás terén, és következésképpen a kompetenciákban is. Az utóbbi években a könyvtárosok és információs szakemberek szakmai identitásának átalakulására a technológiai fejlődés gyakorolta a legnagyobb hatást.

Számos olyan forrás létezik, amely segítségével felderíthetjük és követhetjük az aktuális kompetenciákat a tanulmányi programok fejlesztése és jobbítása érdekében, ezek a következők:

1. a szakterületen működő gyakorlati szakemberek és kutatók által kialakított keretrendszerek vagy modellek;

2. a szakterületen müködő szakemberek nézetei;

3. más felsőoktatási intézmények hasonló tanulmányi programjai;

4. valamint a hallgatók véleménye a tanulmányi programokról.

\section{Keretek és modellek}

A menedzsment területén gyakran használjuk a kompetencia keretrendszerének és modelljének fogalmát, amikor a személyzet bővítésének és fejlesztésének ütemtervét elkészítjük. „A kompetencia keretrendszerében azok az ismeretek, készségek és tulajdonságok szerepelnek,

1 Cedefop. Terminology of European education and training policy: a selection of 130 terms. 2nd ed. Luxembourg, Publications Office. 2014. Forrás: http://www.cedefop.europa.eu/Iv/events-and-projects/projects/validation-non-formal-and-informallearning/european-inventory/european-inventory-glossary\#C [2018. október 31.]

2 Uo.

3 Federal Library and Information Center Committee's (FLICC) Competencies for Federal Librarians. Library of Congress. 2011. Forrás: http://www.loc.gov/flicc/publications/Lib_Compt/2011/2011Competencies.pdf [2018. október 31.]

4 HUVILA, Isto, et al.: What is librarian 2.0. New competencies or interactive relations? A library professional viewpoint. = Journal of Librarianship and Information Science, 45. 3. Sept. 2013. 198-205. p. Forrás: doi:10.1177/0961000613477122 [2018. október 31.] 
amelyekre egy intézmény munkatársai esetében szükség van". Hasonló magyarázatot találunk a kompetenciamodellje esetében: A kompetenciamodell azt határozza meg, hogy milyen jellemzök és teljesitménykövetelmények szükségesek egy bizonyos elvárás teljesitéséhez ${ }^{6}$ vagy bizonyos, a munkakörrel kapcsolatos feladatok elvégzéséhez.

A modellek vagy keretek több cél szolgálnak. Tudásbázisként használhatók:

1. az oktatásban a kurzusok és a tanulmányi programok kiválasztásához, megvalósításához és értékeléséhez: mind a felsőoktatási vagy szakmai, mind a továbbképzésben;

2. a személyzeti menedzsmentben - a jelöltek kiválasztásához egy-egy munkakörre és a teljesítmény értékeléséhez;

3. a szakma marketingjéhez - a szakma társadalmi imázsának kialakításához.

A könyvtár- és információtudomány területén elméleti és empirikus vizsgálatokra építve az egyesületek és más szakmai testületek, illetve kutatók számos keretrendszert vagy modellt fogalmaztak meg.

A szakmai egyesületek által kialakított keretekre néhány példa:

1. A 21. század információs szakembereinek kompetenciái (2014) (Megfogalmazta a Special Libraries Association, USA $)^{7}$;

2. Kompetenciaindex a könyvtári terület számára (2014) (OCLC WebJunction);

3. A tudás szakterületei (Library and Information Association of New Zealand)';

4. A könyvtári és információs szektor: a legfontosabb ismeretek, készségek és tulajdonságok (2014) (Australian Library and Information Association) ${ }^{10}$;

5. A Federal Library and Information Center Committee (FLICC) Kompetenciák a szövetségi könyvtárosok számára címü dokumentuma (2011) (Library of Congress, USA) ${ }^{11}$.

A tanulmányi program megtervezése és a tanterv kifejlesztése során nagyon fontos az összes kompetencia áttekintése, ezért átfogóbb elméleti modellre is szükség van. Egy ilyen Sheila Corrall professzor nevéhez füződik $(2005)^{12}$. Az információs szolgáltatásokhoz szükséges

5 Developing a competency framework. Linking company objectives and personal performance. Forrás: https://www. mindtools. com/pages/article/newlSS_91.htm [2018. október 31.]

6 LAZZARI, Z.:Types of competency models. August 27, 2018.

7 Competencies for information professionals of the 21st century (2014). Forrás: http://infonista.com/wp-content/ uploads/2014/05/Core-Competencies-Revisions-4-30-14-draft.pdf, [2018. november 14.]

8 Competency Index for the Library Field / Compiled by OCLC WebJunction. Forrás: https://www.webjunction.org/content/dam/ WebJunction/Documents/webJunction/2015-03/Competency\%20Index\%20for\%20the\%20Library\%20Field\%20(2014).pdf; [2018. november 14.]

9 Bodies of knowledge. Library and Information Association of New Zealand Aotearoa. Forrás: https://lianza.org.nz/professionalregistration/bodies-knowledge; [2018. október 31.]

10 The library and information sector. Core knowledge, skills and attributes. Australian Library and Information Association. 9 December, 2014. Forrás: https://www.alia.org.au/about-alia/policies-standards-and-guidelines/library-and-informationsector-core-knowledge-skills-and-attributes [2018. október 31.]

11 Federal Library and Information Center Committee's (FLICC) Competencies for Federal Librarians. Library of Congress. 2011. Forrás: http://www.loc.gov/flicc/publications/Lib_Compt/2011/2011Competencies.pdf [2018. október 31.]

12 CORRALL, Sheila: Developing models of professional competence to enhance employability in the network world. = Proceedings of the 6th World Conference on Continuing Professional Development and Workplace Learning for the Library and Information Professions 2005. München, K. G. Saur, 2005. 26-40 p. 
kompetenciákat tartalmazó modellje (1. ábra) három részből áll: a központi részben helyezkednek el a szakmai (technikai) kompetenciák, a második rész tartalmazza a szervezési és menedzsment-kompetenciákat, a harmadik pedig az interperszonális és személyes kompetenciákat. Corrall nézete szerint a személyes kompetenciák olyan alapvető kompetenciák, amelyek szükségesek, de nem elegendőek; a szervezési és menedzsment-kompetenciák lényegesek abból a szempontból, hogy valami lehetővé válhasson (ehhez mind generikus, mind a kontextushoz illeszkedő speciális készségekre/ismeretek kellenek); az interperszonális és személyi kompetenciák pedig olyan túlélési készségek, amelyekre minden szakembernek szüksége van.

\section{Information service competences}

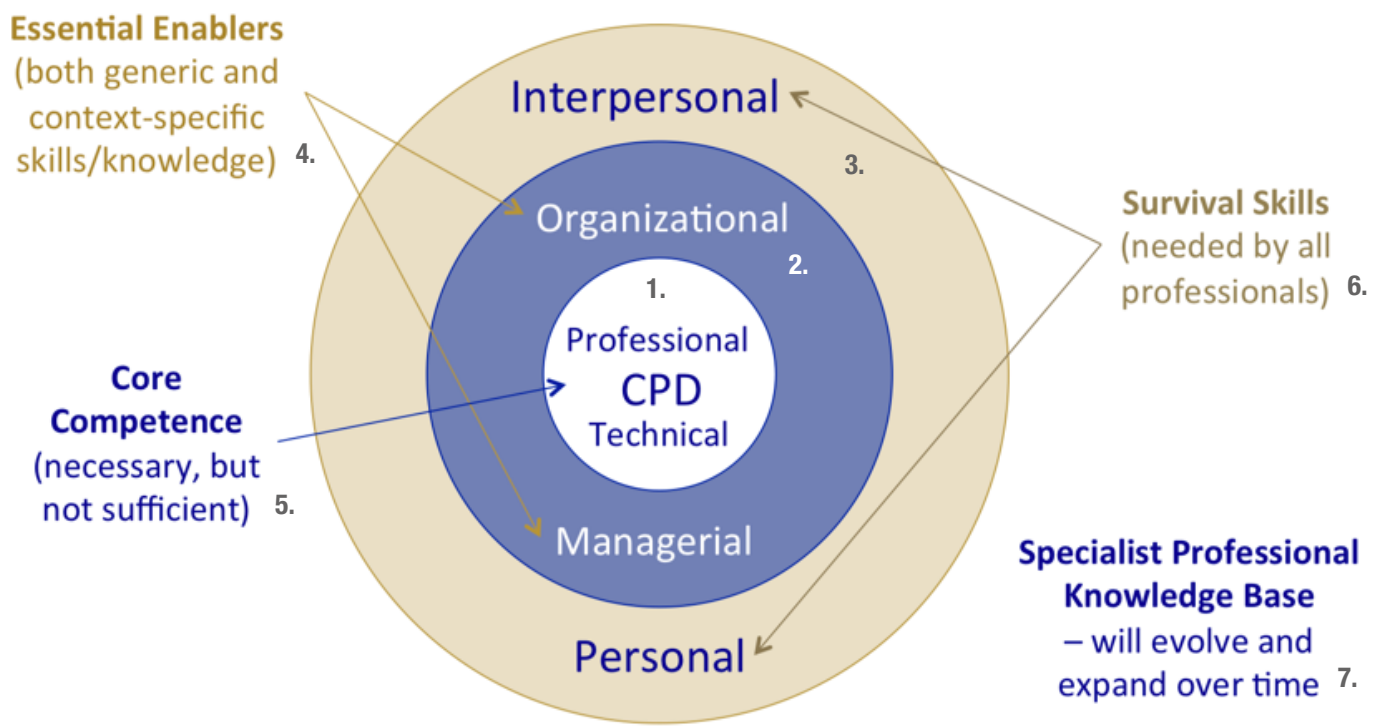

(Corrall, 2005, p. 35)

1. Szakmai - Technikai

2. Szervezési-Menedzsment

3. Interperszonális - személyes

4. Lényeges megvalósítási kompetenciák (ehhez mind generikus, mind kontextushoz illeszkedő speciális készségek, ismeretek kellenek)
5. Alapvető kompetenciák (szükséges, de nem elegendő)

6. Túlélési készségek (ezekre minden szakembernek szüksége van)

7. Speciális szakmai tudásbázis (folyamatosan fejlődik és bővül)

1. ábra: Az információs szolgáltatásokhoz szükséges kompetenciák ${ }^{13}$ 
A szakmai identitást formáló legfontosabb tényezök a szakmai alapkompetenciák ${ }^{14}$. Általában véve közéjük tartoznak az információforrásokkal, a hozzáféréssel, a technológiával és a menedzsmenttel kapcsolatos az ismeretek és készségek.

Az alapkompetenciákat a kompetencia-keretrendszerekben többféleképpen osztályozzák. Például az ALA Special Libraries Association (ALA SLA) keretrendszerében három nagy klaszterbe sorolják ${ }^{15}$ :

A. Együttműködési kapcsolatok létrehozása és fenntartása;

B. Információforrások és információs szolgáltatások menedzselése;

C. Információs eszközök és technológiák megértése és alkalmazása.

Az új-zélandi Library and Information Association (LIANZA) keretrendszerében (Bodies of Knowledge, BOK) a kompetenciákat hat klaszterbe sorolják ${ }^{16}$ :

BOK 1. klaszter: Az információs környezet megértése;

BOK 2. klaszter: Az információs szükségletek, a generációk és a hozzáférés megértése;

$B O K$ 3. klaszter: Az információs források és a tudásmenedzsment megértése;

BOK 4. klaszter: Az információs és kommunikációs technológiák megértése;

BOK 5. klaszter: A menedzsment megértése az információs szervezetekben;

BOK 6. klaszter: A maori tudásparadigmák megértése.

A szakmai alapkompetenciák megfogalmazása a tanterv kialakításának legfontosabb részét jelenti. Átfogó klaszterbe való besorolásuk abban segít, hogy a szükséges tematikus kurzusokat könnyebben tudjuk menedzselni.

A tanulmányi programok fejlesztői általában sokat vitatkoznak, miközben adott kérdésekre keresik a válaszokat, hogy: 1) mennyire legyen általános vagy specifikus egy bizonyos tanulmányi program; 2) milyen tematikus kurzusokat szerepeltessenek a programban, 3) milyen korlátozások fontosak a tanterv létrehozásnál.

Nagy kihívás a szakterület frissen felbukkanó új témáinak felderítése. Az utóbbi években viták folynak a szakirodalomban arról, hogy például hogyan szerepeltessék a könyvtár- és információtudományi tantervekben az adattudományt $\mathrm{t}^{17,18} \mathrm{stb}$. Lin Wang az adattudományt és az információtudományt így írja le, hogy: „szorosan összefüggnek egymással és együtt

14 A szakmai alapkompetenciákat funkcionális kompetenciáknak is nevezik (lásd itt: Federal Library and Information Center Committee's (FLICC) Competencies for Federal Librarians. Library of Congress. 2011. Forrás: http://www.loc.gov/flicc/ publications/ Lib_Compt/2011/2011Competencies.pdf [2018. október 31.]), vagy tudományterületekhez kötődő tudásnak. - RAJU, J.: Knowledge and skills for the digital era academic library. = The Journal of Academic Librarianship. 40. 2. 2014. 163-170 p. [2018. október 31.]

15 Competencies for information professionals of the 21st century (2014). Forrás: http://infonista.com/wp-content/ uploads/2014/05/Core-Competencies-Revisions-4-30-14-draft.pdf [2018. október 31.]

16 Bodies of knowledge. Library and Information Association of New Zealand Aotearoa. Forrás: https://lianza.org.nz/professionalregistration/bodies-knowledge [2018. október 31.]

17 FEDERER, Lisa: Defining data librarianship. A survey of competencies, skills, and training. = Journal of the Medical Library Association, 106. 2. July 2018. 294-303. p. Forrás: doi:10.5195/jmla.2018.306. [2018. október 31.]

18 WANG, Lin: Twinning data science with information science in schools of library and information science. $=$ Journal of Documentation, 74. 6. 2018. 1243-1257. p. Forrás: doi:10.1108/JD-02-2018-0036. [2018. október 31.] 
alkotják az 'információs lánc' kutatásának elemeit”'19 és mindkét tudományterületnek ugyanaz a küldetése és természete. Meggyőződése, hogy az adattudomány integrálása az információtudományi programokba értékes lehet a könyvtár- és információtudományi programok fejlesztésére nézve.

Amikor új fejleményeket észlelünk, az megváltoztathatja gondolkodásmódunkat. Sheila Corrall20 szerint: „Ujj koncepciók és modellek alakultak ki, ilyen például a blended (kevert) könyvtárosság, a beépitett információszolgáltatók, a 'kifordított' gyüjtemények, a részvételi könyvtár és a tér mint szolgáltatás. A támogató szolgáltatásról áttérés történt a közös munkavégzésre és a multidiszciplináris partnerségre, ami jelentös hatással van a kompetenciák fejlödésére, ezáltal elöidézték azt az igényt, hogy T-alakú, Pi-alakú és a fésü-alakú emberekre van szükség. Új keretek kellenek ahhoz, hogy kifejezzük azokat a speciális és általános ismereteket, készségeket és képességeket, amelyekre a 21. század határokat feszegetö szerephez szükség van”.

\section{Breaking Down Silos Encourages People to Grow}

1.

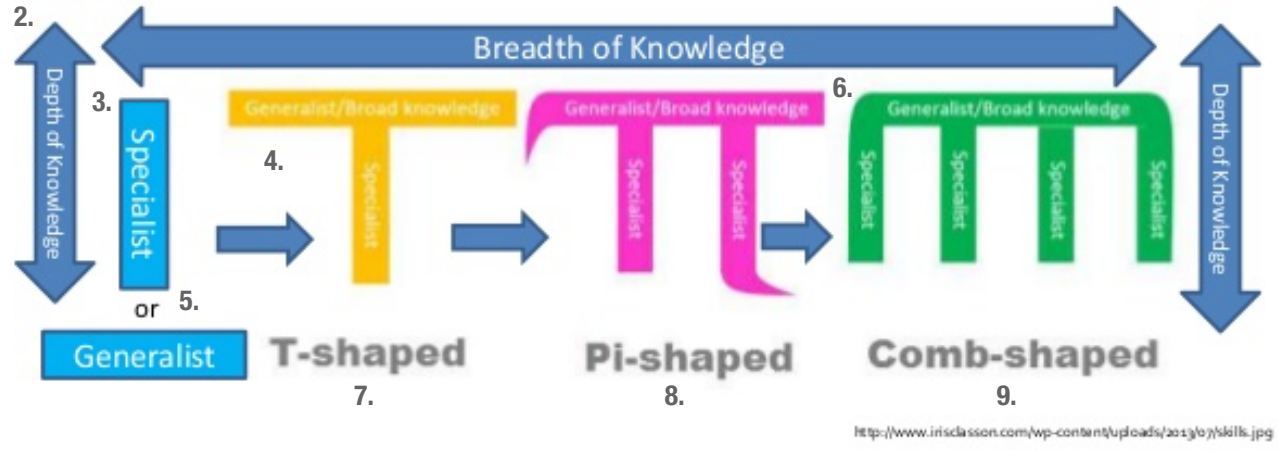

optimising the flow from idea to value realisetion

1. Átfogó tudás

2. A tudás mélysége

3. Specialista
4. Általános szakember/átfogó tudás

5. vagy

6. Általános szakember/átfogó tudás
7. T-alakú

8. Pi-alakú

9. Fésü-alakú

2. ábra: T-alakú, Pi-alakú és a Fésü-alakú emberek tudásképe vertikálisan és horizontálisan ${ }^{21}$

19 Uo.

20 CORRALL, Sheila: Educating the academic librarian as a blended professional. A review and case study. = Library Management, 31. 8/9. 2010. 567-593. p., Forrás: https://doi.org/10.1108/01435121011093360. [2018.október 31.]

21 https://www.ranger4.com/ [2018. október 31.]; BEAL, Helen: What is a Dev0ps test engineer? Forrás: https://www.slideshare. net/Dev0pstastic/what-is-a-devops-test-engineer [2018. október 31.] 
Az alapkompetenciákról és az interperszonális és személyes kompetenciákról való tájékozódásban fontos forrásokat jelentenek a szakterület szakemberei. Nézeteiket és információszerzési módszereiket e tanulmányban később ismertetjük.

A modell második köre (1. ábra) a menedzsmenttel és szervezéssel kapcsolatos könyvtárosi kompetenciákat tartalmazza. A könyvtár típusától függően (felsőoktatási, köz-, gyermekkönyvtár stb.) a könyvtárosoknak speciális ismeretekre és készségekre van szükségük, amelyeket megtanulhatnak tanulmányaik során és a munkahelyen is. A modellben (1. ábra) a harmadik kör az interperszonális és személyes kompetenciákat mutatja be. ${ }^{22}$ Ezek „olyan alapvetö vagy közös kompetenciák, amelyek több funkcionális területen és a szakmai pályafutás több szakaszában szerepelnek”. ${ }^{23}$ Néhány kutatás azt fontolgatja, hogy külön kell választani az úgynevezett generikus készségeket és a személyes kompetenciákat vagy tulajdonságokat. ${ }^{24}$

A 21. század oktatási modelljeire építve ${ }^{25}$ vannak olyan kompetenciák (generikus készségek), amelyek mindenki számára fontosak a században (kritikus gondolkodás/problémamegoldás, kreativitás; érzelmi intelligencia, szolgáltatás-orientáció, együttműködés stb.). Vannak olyan személyes kompetenciák is, amelyek speciálisan egy bizonyos információs területre nézve lényegesek. Az ALA Special Libraries Association által kialakított keretrendszerben ez áll: „A személyes kompetenciák a viselkedés, készségek és értékek olyan készletét képviselik, amelyek révén a gyakorló szakemberek hatékonyan képesek dolgozni és pozitívan hozzá tudnak járulni az adott szervezet, az ügyfelek és a szakma életéhez. Ezek a kompetenciák az állandóan változó környezetben az eröteljes kommunikátori szereptöl szakmai tevékenységük hozzáadott értékének bemutatásáig terjedhetnek. Az Australian Library and Information Association a következő készségeket sorolja fel: hatékony kommunikáció, önmenedzsment, számvitel, partneri kapcsolatok és szövetségek építése, hatékony csoportkapcsolatok, felügyelet, marketing. ${ }^{26}$ E kompetenciák (alapkompetenciák) leírása szerepel a Competencies for Federal Librarians ${ }^{27}$ címü dokumentumban. Az alapkompetenciákat hat csoportba sorolják: kognitív elemzések, kommunikáció, érzelmi intelligencia, irányítás, szaktudás, technológia alkalmazá$s a$, és mindegyik csoport az odasorolható speciális képességek jegyzékét tartalmazza. Például

22 Az interperszonális és személyes készségeket megalapozó készségeknek is nevezik, például itt: Federal Library and Information Center Committee's (FLICC) Competencies for Federal Librarians. Library of Congress. 2011. Forrás: http://www.loc.gov/flicc/ publications/Lib_Compt/2011/2011Competencies.pdf [2018. október 31.], és generikus készségeknek itt: The Library and Information Sector. Core knowledge, skills and attributes. Australian Library and Information Association. 9 December, 2014. Forrás: https://www.alia.org.au/about-alia/policies-standards-and-guidelines/library-and-information-sector-core-knowledgeskills-and-attributes ; [2018.október 31.], és generikus készségeknek és személyes kompetenciáknak itt: Raju, J.: Knowledge and skills for the digital era academic library. = The Journal of Academic Librarianship, 40. 2. 2014. 163-170 p. https://doi. org/10.1016/j.acalib.2014.02.007 [2018. október 31.]

23 Federal Library and Information Center Committee's (FLICC) Competencies for Federal Librarians. Library of Congress. 2011. Forrás: http://www.loc.gov/flicc/publications/Lib_Compt/2011/2011Competencies.pdf [2018. október 31.]

24 RAJU, J.: Knowledge and skills for the digital era academic library. = The Journal of Academic Librarianship, 40. 2. 2014. 163-170 p. https://doi.org/10.1016/j.acalib.2014.02.007 [2018. október 31.]

25 Competencies for information professionals of the 21st century (2014). Forrás: http://infonista.com/wp-content/ uploads/2014/05/Core-Competencies-Revisions-4-30-14-draft.pdf [2018. november 14.]

26 The library and information sector. Core knowledge, skills and attributes. Australian Library and Information Association. 9. December, 2014. Forrás: https://www.alia.org.au/about-alia/policies-standards-and-guidelines/library-and-information-sectorcore-knowledge-skills-and-attributes [2018. október 31.]

27 Federal Library and Information Center Committee's (FLICC) Competencies for Federal Librarians. Library of Congress. 2011. Forrás: http://www.loc.gov/flicc/publications/Lib_Compt/2011/2011Competencies.pdf [2018. október 31.] 
a kognitív elemzések között olyan képességek szerepelnek, mint: a részletekre való figyelés, kreatív gondolkodás, döntéshozatal, matematikai érvelés, problémamegoldás, vitakészség.

$\mathrm{Az}$ interperszonális és személyi kompetenciák általában közvetetten szerepelnek a tantervekben - mint olyan készségek, amelyek a tanulási feladatok (csoportmunka, prezentációk, projektek) teljesítéséhez szükségesek. A hallgatók ezeket a készségeket többnyire a gyakorlatban tanulva sajátítják el, de van néhány olyan kompetencia is, amely tantárgyként szerepel a tanmenetben (marketing, projektmenedzsment stb.).

A kompetenciamodelleket vagy kereteket gazdagítják azoknak a szakembereknek a szempontjai, akik a napi gyakorlatban szereznek tapasztalatokat. Ök segíthetnek „a modelleket a való világ összefüggéseibe helyezni”.

\section{A terepen dolgozó könyvtárosok mint információforrások}

Számos lehetőség nyílik arra, hogy gyakorló szakemberektől szerezzünk információt a szükséges kompetenciákról (kérdőíves felmérések, a Delphi módszer, fókuszcsoportos megbeszélések, interjúk stb.).

Jenny Bronstein és Ora Nebenzah ${ }^{28}$ azt állapították meg, hogy a felméréseket meglehetősen gyakran arra használják, hogy a könyvtárosok nézeteit és érzeteit vizsgálják a szükséges készségekkel és kompetenciákkal kapcsolatban. A két szerző gyakorló szakemberek nézetei és véleményei alapján, különböző skálákat használva azt kutatta, hogy milyen készségeket és kompetenciákat tartanak szükségesnek az izraeli könyvtár-és információtudományi tantervben. Az eredmények azt mutatják, hogy a legfontosabbak a technológiai készségek hogy jobban megértsék a használókat, azok viselkedését és interakcióját a könyvtári termékekkel és szolgáltatásokkal. Fontosak még az információkeresési készségek. Ennek az az oka, hogy a használók gyakran kérnek segítséget a könyvtárosoktól a részletesebb és komplex keresések elvégzéséhez. A szerzők arra a következtetésre jutnak, hogy a használók információs jártassági szintjének különbségeivel és „... a használók és az információ közötti közvetítő szereppel magyarázható, hogy szükség van olyan kompetenciákra, mint az interperszonális kapcsolatok, a kommunikációs készségek és a csoportmunka." ${ }^{29} \mathrm{E}$ kutatás szerint nem annyira fontos, hogy a formális oktatásban tanítsák meg a következő készségeket: munkavégzés nagy megterhelés mellett, könyvtári programok használata és oktatási készségek, mivel ezek megtanulhatók munka közben ${ }^{30}$.

2016-ban a Lettországi Egyetem Információ- és Könyvtártudományi Tanulmányok Tanszéke Delphi módszerrel felmérést végzett, hogy megismerje a gyakorló szakemberek véleményét a tanulmányi programokban szereplő tantervekbe foglalt, szükségesnek vélt

28 BRONSTEIN, Jenny - NEBENZAH, Ora: Developing scales for identifying and classifying library and information science skills and competencies. An Israeli perspective. = Journal of Librarianship and Information Science, Aug. 2018, Forrás: doi:10.1177/0961000618792390. [2018. október 31.] 
kompetenciákról. A kérdőíveket két ízben küldték ki egy szakértői csoport számára, amely 45 könyvtárosból állt (53\%-uk rendelkezett mester szintű könyvtárosi végzettséggel), akik különböző típusú könyvtárakban dolgoztak. A szakértőknek (a válaszadóknak) a Likertskálán értékelniük kellett a szükséges kompetenciákat, hogy azok az általános vagy a tematikus kompetenciák körébe tartoznak-e.

Az eredmények azt mutatják, hogy az általános kompetenciák csoportjában a következők a fontos készségek: különbözö kommunikációs készségek (98\%); kritikus gondolkodás és helyzetelemzési készségek (98\%); készség a teammunkára (98\%); együttmüködési készségek (90\%), prezentációs készségek (90\%). A válaszolók több mint 80\%-a egyetért abban, hogy fontos készségek a problémamegoldás (85\%); a viselkedési szabályok ismerete (85\%), a pedagógiai készségek és ismeretek (83\%), a lélektan (83\%), a kreativitás (83\%), és hasznosak az idögazdálkodással és a feladatok kezelésével kapcsolatos készségek is (78\%).

A speciális kompetenciákat négy csoportra osztották tovább: információforrások kezelése; könyvtári menedzsment; az információs szolgáltatások menedzselése; technológiai kompetenciák. Az információforrások kezelésének területéről a legelterjedtebb nézőpont szerint a következők ismerete szükséges: szerzői jog (93\%); adatokkal kapcsolatos írástudás (92\%); kompetenciák az adatbázisok és az online katalógusok fejlesztésére (90\%); könyvtári információs rendszerek menedzselése (90\%); elektronikus források és minden információforrás kezelése (90\%), adat- és információbiztonságai kérdések (83\%). A könyvtári menedzsment alcsoportban a legmagasabb pontszámot a jogszabályokkal és egyéb szabályozással és a könyvtári közönségkapcsolatokkal kapcsolatos kompetenciák kapták (91\%). Fontosnak bizonyultak a változások kezelésével (88\%), a más intézményekkel való együttmüködéssel (86\%) és a pénzügyek kezelésével kapcsolatos kompetenciák (82\%). Az információs szolgáltatások menedzselése alcsoportban a legfontosabb kompetenciák a pedagógiai ismeretek és az információs jártassággal kapcsolatos készségek (100\%); a felhasználóknak nyújtott szolgáltatások megszervezése (98\%); ezeket követi az egyes használói csoportoknak nyújtott szolgáltatások megszervezése, a helyismeret, a könyvtári környezet és tér megszervezése (93\%); és a szolgáltatások minöségének és a használók elégedettségének értékelése (89\%). A technológiai kompetenciák alcsoportban a legfontosabbak az internetes információbiztonság (100\%), a keresőmotorok és adatbázisok hatékony használatát szolgáló kompetenciák és az internetes helyek fejlesztése (99\%), a számítógépek és hasonló eszközök hatékony használata (93\%).

Egy évvel később, 2017-ben a Tanszék fókuszcsoportos vitát szervezett a szakma képviselőivel, ahol tovább vizsgálták a szükséges kompetenciákat és azt, hogy mennyire készülnek a hallgatók könyvtárakban elhelyezkedni. A vita segített tisztázni a következő kérdéseket 1) a programokban szereplő kompetenciák hiányosságait (például nem szerepel kurzus a kortárs szépirodalomról, és a használók képzéséhez szükséges pedagógiai készségekről); 2) a kurzusok relevánsabb megnevezését; 3) a kurzusok logikus sorrendjét; és 4) a program végzettjeinek készségét, hogy könyvtárban helyezkedjen el.

A tantervek fejlesztéséhez hasznos ötletek találhatók más egyetemek hasonló tanulmányi programjaiban, akár hasonló történelmi fejlödésü és hagyományú országokról van szó, akár olyan országokról, ahol másfajta tapasztalatok állnak rendelkezésre a könyvtár- és 
információtudományi oktatás területén (például az iSchools képzőintézményeinek tanulmányi programjai esetében). Más tanulmányi programok is lehetnek új kurzuscímek és -tartalmak forrásai, és inspirációt adhatnak a tanterv struktúrájának fejlesztéséhez.

A tanulmányi programokról szóló információk forrásai általában a hallgatók és a végzettek értékelései és véleménye, amelyet az egyes szemeszterek vagy tanulmányok végeztével folytatott felmérések eredményei szolgáltatnak. Ez a megoldás tájékoztatást ad a tanított kurzusok helyzetéről; a tartalom minőségéről, az oktatási módszerekről, a támogató szolgáltatásokkal (könyvtár, hozzáférés a forrásokhoz, konzultációk stb.) és a tanulmányi programmal való elégedettségről általában. Egyéni interjúkkal vagy fókuszcsoportos megbeszéléssel további információkhoz lehet jutni a hallgatók elvárásairól és a megszerzett kompetenciákról.

A tanulmányi folyamat számos tényezőt befolyásol: az oktatás megszervezését és a használt tanítási módszereket; a hallgatók motivációját és elvárásait, a tanárok kompetenciáit az adott tantárgyat illetően. Ezeket a tanulmányi folyamatban kihívásoknak tekinthetjük. Az utóbbi években nagy hangsúlyt helyeznek a tanítási módszerek korszerüsítésére. Kutatásokra alapozva ${ }^{31}$ olyan módszerek használatát sugallják, amelyek megkönnyítik a hallgatók számára az önálló tájékozódást, a megoldások megtalálását, gondolkodásmódjuk és érvelésük fejlesztését. Az oktatással úgy lehet a legjobb eredményeket elérni, ha a tananyag memorizálása mellett olyan módszerek dominálnak, amelyek az érveléssel, a mély tanulással, a belső motivációval, a kritikus gondolkodással, a nem rutin jellegü problémákkal kapcsolatosak. Ahogy a problémák egyre nehezebbek, a memorizálás egyre kevésbé hasznos, sokkal hasznosabbak a problémák feldolgozására irányuló stratégiák.

\section{Következtetések}

A társadalom változásai általában és az információs világ változásai különösen számottevő hatást gyakorolnak a könyvtár- és információtudományi oktatásra. Számos olyan forrás áll rendelkezésre, amelyek segítségével nyomon követhetők a könyvtárosok kompetenciái, amelyekre a munkájuk során szükségük van, melyek a következők: empirikus és elméleti modellek vagy kompetencia-keretrendszerek, szakemberek nézetei, más tanulmányi programok, valamint a hallgatók és a végzettek véleménye. Minden forrásnak megvannak az előnyei: a keretrendszerek és a modellek segítségével teljes képet lehet kialakítani a kompetenciákról; a szakemberek nézeteit és véleményét felhasználva valós élethelyzetben lehet meghatároznia a keretrendszereket és modelleket; a hasonló tanulmányi programok új ötleteket inspirálhatnak, és „szerepmodellként” szolgálhatnak; a hallgatók és végzettek véleménye pedig segíthet az oktatási folyamat jobbításában.

31 SCHLEICHER Andreas: What knowledge, skills, attitudes and values will today's students need to thrive and shape their world.2018. Forrás: https://www.slideshare.net/OECDEDU/what-knowledge-skills-attitudes-and-values-will-todays-studentsneed-to-thrive-and-shape-their-world. [2018. október 31.] 
„A felsőoktatási programoknak választ kell adniuk a szakterületen felmerülö trendekre, tekintetbe kell venniük a kutatók és a gyakorlati szakemberek által felvetett innovatív gondolatokat és ötleteket, és elöre kell vetíteniük a szolgáltatások új modelljeit.”32

\section{Irodalom}

BEAL, Helen: What is a DevOps est engineer? Forrás: https://www.slideshare.net/DevOpstastic/whatis-a-devops-test-engineer [2018. október 31.]

Bodies of knowledge. Library and Information Association of New Zealand Aotearoa.

Forrás: https://lianza.org.nz/professional-registration/bodies-knowledge [2018. október 31]

BRONSTEIN, Jenny - NEBENZAH, Ora: Developing scales for identifying and classifying library and information science skills and competencies. An Israeli perspective. = Journal of Librarianship and Information Science, Aug. 2018, Forrás: doi:10.1177/0961000618792390 [2018.október 31.]

Cedefop. Terminology of European education and training policy: a selection of 130 terms. 2nd ed. Luxembourg, Publications Office. 2014. Forrás: http://www.cedefop.europa.eu/lv/events-and-projects/projects/validation-non-formal-and-informal-learning/european-inventory/european-inventory-glossary\#C [2018. október 31.]

Competencies for information professionals of the 21st century (2014). Forrás: http://infonista.com/ wp-content/uploads/2014/05/Core-Competencies-Revisions-4-30-14-draft.pdf [2018. november 14.]

Competency Index for the Library Field. Compiled by OCLC WebJunction.

Forrás:https://www.webjunction.org/content/dam/WebJunction/Documents/webJunction/2015-03/

Competency\%20Index\%20for\%20the\%20Library\%20Field\%20(2014).pdf; [2018. november 14.]

CORRALL, Sheila: Educating the academic librarian as a blended professional. A review and case study. = Library Management, 31. 8/9. 2010. 567-593. p. Forrás: https://doi.org/10.1108/01435121011093360 [2018.október 31.]

CORRALL, Sheila: Developing models of professional competence to enhance employability in the network world. $=$ Proceedings of the 6th World Conference on Continuing Professional Development and Workplace Learning for the Library and Information Professions 2005. München, K.G. Saur, 2005. 26-40 p. [2018.október 31.]

Developing a competency framework. Linking company objectives and personal performance. Forrás: https://www.mindtools.com/pages/article/newISS_91.htm [2018. október 31.]

Federal Library and Information Center Committee's (FLICC) Competencies for Federal Librarians. Library of Congress. 2011. Forrás: http://www.loc.gov/flicc/publications/Lib_Compt/2011/2011Competencies.pdf [2018. október 31.]

FEDERER, Lisa: Defining data librarianship. A survey of competencies, skills, and training. = Journal of the Medical Library Association. 106. (July) 2. 2018. 294-303. p. Forrás: doi:10.5195/jmla.2018.306 [2018. október 31.]

HUVILA, Isto, et al.: What is librarian 2.0. New competencies or interactive relations? A library professional viewpoint. = Journal of Librarianship and Information Science, 45. 3. Sept. 2013. 198-205. p., Forrás: doi:10.1177/0961000613477122 [2018. október 31.]

LAZZARI, Z.: Types of competency models. August 27, 2018.

32 CORRALL, Sheila: Educating the academic librarian as a blended professional: a review and case study = Library Management, 31. 8/9. 2010. 567-593 p. Forrás: https://doi.org/10.1108/01435121011093360 [2018.október 31.] 
The library and information sector. Core knowledge, skills and attributes. Australian Library and Information Association. 9 December, 2014. Forrás: https://www.alia.org.au/about-alia/policies-standards-and-guidelines/library-and-information-sector-core-knowledge-skills-and-attributes [2018. október 31.]

RAJU, J.: Knowledge and skills for the digital era academic library. = The Journal of Academic Librarianship, 40. 2. 2014. 163-170 p. https://doi.org/10.1016/j.acalib.2014.02.007 [2018. október 31.]

SCHLEICHER, Andreas: What knowledge, skills, attitudes and values will today's students need to thrive and shape their world. 2018. Forrás: https://www.slideshare.net/OECDEDU/what-knowledgeskills-attitudes-and-values-will-todays-students-need-to-thrive-and-shape-their-world [2018. október 31.]

SOFFEL, Jenny: What are the 21st-century skills every student needs? 10 March, 2016. Forrás: https:// www.weforum.org/agenda/2016/03/21st-century-skills-future-jobs-students/ [2018. október 31.]

WANG, Lin: Twinning data science with information science in schools of library and information science. $=$ Journal of Documentation, 74. 6. 2018. 1243-1257. p. Forrás: doi:10.1108/JD-02-2018-0036 [2018. október 31.]

Baiba Holma a Lettországi Egyetem (Riga) Társadalomtudományi Karán a Tájékoztatásés Könyvtártudományi Tanszék adjunktusa. 2004 óta az Információmenedzsment kurzus igazgatója, ebben a minőségében igyekszik lépést tartani a könyvtárosok és tájékoztató szakemberek korszerü kompetenciáival. Az alap- és a mesterképzésben is számos tárgyat tanít. Kutatási érdeklődése sokrétü: a szemantikus visszakereséstől az információs írástudáson át (különös tekintettel a felnőttek mindennapi információs írástudására) a könyvtári munkában folyó innovációig és a könyvtárosképzés kérdéseiig terjed. 